\title{
LOCUS OF CONTROL ON ATHLETES FACING MATCH
}

\author{
Johannes Pangaribuan \\ Email address : johanesp6@gmail.com \\ Faculty of Psychology, Gunadarma University, Depok, Indonesia
}

\begin{abstract}
Locus of control (LOC) is one of the psychological aspects that affect the athlete's appearance in competing. This study aims to look at the description of LOC in athletes and the factors that cause the appearance of LOC in athletes. Researchers used a case study approach and data collection by direct interviews with a 21-year-old subject who was a wushu athlete. The results showed the subject has the characteristics of an athlete with a locus of control that tends to be internal, this can be seen from the subject's efforts to achieve his life goals, the subject does not give up easily and give up in the face of a competition. The subject chooses to keep trying in a match even though the opponent is very difficult. The factors that cause the emergence of LOC in the subject include age, family and environment
\end{abstract}

Keywords : : locus of control; athletes; facing the competition;

1. Introduction

Sports are activities that include physical, technical and psychological aspects. The peak sports achievement is the actualization of these three aspects. The physical aspect is the condition of the athlete related to the morphological and anthropometric structures that are actualized in achievement, the technical aspect is the potential that the athlete has and can develop optimally to produce certain achievements, while the psychological aspect is related to the structure and function of both characterological and cognitive aspects of the psychic that support it. actualization of potential and seen in the achievements achieved (Singer in Gunarsa, 1996).

The performance of an athlete is influenced by several factors, namely: physical, technical, tactical and mental or psychological factors, coaches, training facilities and infrastructure, training, and so on. These factors have a very close relationship with one another (Gunarsa, 1996).

According to Harsono (in Gunarsa, 1996), 80\% of an athlete's peak performance is influenced by mental aspects and only $20 \%$ by other aspects. Furthermore, Garfield (in Gunarsa, 1996) explicitly states that most athletes who reach the peak of achievement as much as $60 \%$ to $90 \%$ are influenced by mental factors and the athlete's ability to control their psychological conditions. This condition requires someone to be able to control themselves.

Self-control or Locus of control / LOC was first proposed by Rotter (1966), a social learning theorist. Locus of control is one of the personality variables, which is defined as an individual's belief in his or her own destiny (Kreitner \& Kinicki, 2005).

Locus of controlitself is divided into two, namely the internal locus of control and the external locus of control. Internal locus of control is individuals who believe that they are in control of whatever happens to them whereas external locus of control is individuals who believe that whatever happens to them is controlled by outside forces such as luck and opportunity (Robbins \& Judge, 2007). ). Findly \& Cooper (in Zaroh, 2000) explains that locus of control is the way individuals perceive situations outside themselves, among others, determined by the control center that exists in the individual. The differences in orientation that exist in individuals or in each person lead to attitudes and ultimately lead to application and efficiency and effectiveness of behavior.

According to Jung (1978), people who have an internal locus of control have the belief that the individual himself is responsible for the success and failure he experiences. These successes and failures are the result or result of their own abilities or efforts. Meanwhile, external locus of control shows the individual's belief that what happens to him, namely the success or failure he experiences is determined by forces outside himself, for example because of fate, luck, opportunity, and other people's power and even becomes his responsibility. For example, before competing, the athlete perceives that he is at that time less fortunate because he meets a strong opponent, so the athlete will tend to put less effort into the match (external locus of control).

Atlets that internalize success exhibit emotional responses linked to pride, confidence, competence, and satisfaction. In contrast, athletes who successfully externalize display emotional responses associated with gratitude, gratitude and luck. Athletes who internalize failure (self-blame) exhibit emotional influences related to guilt, shame, inadequacy, and depression. In contrast, athletes who externalize failure show emotional responses IJRP 2022, 92(1), 98-105; doi:.90.471191/IJRP100921120222681. This is a highly predictable response and provides an observant 
coach, teacher, or parent with valuable information about the athlete's motivation (Singer, Murphey \& Tennant, 1993).

Differences in locus of control will determine the tendency to use strategic patterns in dealing with problems (Persitarini, 1988). Individuals with internal locus of control will try to face problems and overcome them by using existing resources within themselves, while individuals with external locus of control will try to avoid problems, because they feel that they are unable and unable to survive to overcome the situation at hand. where this defense only tries to relieve emotions and tension (Robbins, 1989).

Conditions and environment at the venue will affect the mental of an athlete. Athletes with good internal locus of control will try to adapt to the conditions and situations at the competition venue, on the other hand, athletes with a strong external locus of control will tend to be lazy to adapt and will not try. A star athlete should be able to adapt to various situations. That was the statement by Gilian Gilks, a British badminton player a few years ago when asked about the hot air of the Senayan city which hindered his ability to play against Indonesian national players. Gilks realized how hot the Jakarta air was, especially in the Senayan office which was not yet air-conditioned and the audience was still allowed to smoke.

The role of a coach will also affect the mentality of the athlete. Roberts (1984) explains that if the coach scoffs at the athlete by saying stupid, incapable (low ability), the athlete tends to reduce the effort further and even stop trying. For example, before the match, the coach tells the athlete that he will not be able to win the competition because the opponent's ability is much better than his, for an athlete with a strong external locus of control, the coach's words will affect the athlete's mental and the athlete may put less effort into the competition because he feels he is going to lose.

The results of this study have proven that the internal locus of control orientation has more positive consequences. Research conducted by Astiningsih et al (2010) shows that individuals who have this internal locus of control are characterized as independent, persevering, strong, and easy to trust in others, and have a strong resistance to social influences. In addition, individuals who have this internal locus of control have a willingness to take responsibility, are easily motivated, have high fighting spirit, are persistent, and have the guts to fight with risks. Meanwhile, individuals with this external locus of control believe that their life path has been determined and tend to feel that the actions they take do not have much effect on the results to be achieved. This individual also tends to believe in fate,

According to the description above, Locus of control (LOC) is one of the psychological aspects that affects the athlete's performance in competition. Athletes with internal locus of control believe in success because of their own efforts, have a strong sense of self-confidence and if they lose a match they don't blame others, are aware of their defeat and are increasingly practicing diligently. Compared with external locus of control athletes who believe in winning because of luck, have less self-confidence, when they meet tough opponents they will avoid and when they lose they will blame other factors. Therefore, the researcher wants to see how LOC is described in athletes? and what factors cause the appearance of LOC in athletes?

\section{Method}

This study aims to determine the description of the locus of control in athletes in the face of a competition and also to determine the factors that cause the emergence of locus of control in athletes in the face of a competition. This research approach is a qualitative approach in the form of case studies.

According to Keirk and Miller (in Moloeng, 2004) what is meant by qualitative research is a particular tradition in social science that fundamentally depends on observations, humans, their own areas and their relationships with these people in their discussion and terminology.

Characteristics of the subject that will be used in this study is a male athlete who has participated in a regional competition with the age of 20 years. In addition to interviewing the subject, the researcher also interviewed the significant other, namely the closest person to the subject who knows about the life and daily life of the subject.

In research, the number of subjects in this study is one (1) person, as well as the significant other, which amounts to one (1) who is a close friend of the subject. The data was collected using observation and open interviews. The interview was conducted three times for subject with a duration of approximately 45 minutes/interview. the researcher asked several questions in connection with this research case based on the guidelines that had been made. During the interview process, the researcher always made field notes. When asking questions and listening to the answers from subject.

In observations, researchers directly observe the activities of the subject. With the hope of research obtaining additional information that cannot be obtained from interviews, as well as knowing the suitability of information obtained from interviews with the daily activities of the subject, it can be obtained from observations. 
3. Result and Discussion

Based on the results of interviews and observations with subjects in this study, we obtained several themes regarding locus of control at subject. Those themes are in the table 1.1 below

Tabel 1.1 Description Locus of Control

\begin{tabular}{|c|c|c|c|c|}
\hline No & Theme & Subjek & Significant other & Conclusion \\
\hline 1. & Biography & $\begin{array}{l}\text { Subject is the third } \\
\text { child of three siblings } \\
\text { The subject currently } \\
\text { lives in Depok and } \\
\text { comes from Central } \\
\text { Java. Subject is also } \\
\text { working as a sanshao } \\
\text { trainer at one of the } \\
\text { private universities. }\end{array}$ & $\begin{array}{l}\text { Significant other is the } \\
\text { trainer as well as the } \\
\text { subject's work partner. } \\
\text { According to a } \\
\text { significant other, the } \\
\text { subject is an } \\
\text { independent person, an } \\
\text { overseas resident in } \\
\text { Jakarta who comes } \\
\text { from Central Java and } \\
\text { the subject is aperson } \\
\text { who cares about his } \\
\text { family, has an athlete } \\
\text { lifestyle and is ignorant } \\
\text { of criticism. Currently } \\
\text { the subject also works } \\
\text { as an assistant trainer in } \\
\text { Jakarta to make ends } \\
\text { meet }\end{array}$ & $\begin{array}{l}\text { The subject is an } \\
\text { independent person } \\
\text { and comes from } \\
\text { Central Java. In } \\
\text { Jakarta, the subject } \\
\text { becomes a trainer at a } \\
\text { private university and } \\
\text { also becomes his } \\
\text { assistant trainer to } \\
\text { make ends meet }\end{array}$ \\
\hline 2. & Background & $\begin{array}{l}\text { The subject initially } \\
\text { practiced wushu since } \\
\text { high school in East } \\
\text { Kalimantan. The } \\
\text { subject was initially } \\
\text { interested after seeing } \\
\text { that there was a wushu } \\
\text { extracurricular activity } \\
\text { in his school and the } \\
\text { subject felt that he } \\
\text { was suitable in wushu } \\
\text { and until now he } \\
\text { continues to practice } \\
\text { wushu and become a } \\
\text { wushu athlete. }\end{array}$ & $\begin{array}{l}\text { significant other knows } \\
\text { if the subject is high } \\
\text { school in one of the } \\
\text { Islamic boarding } \\
\text { schools in East } \\
\text { Kalimantan. According } \\
\text { to the significant other, } \\
\text { the subject really likes } \\
\text { wushu and wants a } \\
\text { career in wushu. }\end{array}$ & $\begin{array}{l}\text { Subject is high school } \\
\text { in East Kalimantan } \\
\text { and followed wushu } \\
\text { since high school. The } \\
\text { subject also really } \\
\text { likes wushu and wants } \\
\text { a career in the world } \\
\text { of wushu. }\end{array}$ \\
\hline . & $\begin{array}{l}\text { Overview of Dare to take risks } \\
\text { Internal Locus of } \\
\text { control }\end{array}$ & $\begin{array}{l}\text { In making decisions, the } \\
\text { subject is ready to face } \\
\text { the risks the subject will } \\
\text { receive from the } \\
\text { decisions he makes. }\end{array}$ & $\begin{array}{l}\text { According to } \\
\text { significant other, the } \\
\text { subject when it fails } \\
\text { will be disappointed. } \\
\text { But the subject will also } \\
\text { quickly return to } \\
\text { bounce back on its } \\
\text { own. }\end{array}$ & $\begin{array}{l}\text { The subject dares to } \\
\text { take risks from the } \\
\text { decisions the subject } \\
\text { takes and when it fails } \\
\text { the subject will be } \\
\text { disappointed. } \\
\text { Despite being } \\
\text { disappointed by his } \\
\text { failure, the subject } \\
\text { will also be quick to } \\
\text { bounce back }\end{array}$ \\
\hline
\end{tabular}


Continue Tabel 1.1 Description Locus of Control

\begin{tabular}{|c|c|c|c|c|c|}
\hline No & Theme & & Subject & Significant other & Conclusion \\
\hline 3 & $\begin{array}{l}\text { Overview of } \\
\text { Internal } \\
\text { Locus of } \\
\text { control }\end{array}$ & $\begin{array}{l}\text { Not easily } \\
\text { give up }\end{array}$ & $\begin{array}{l}\text { The subject when } \\
\text { losing the match, the } \\
\text { subject introspect and } \\
\text { reflect on what was } \\
\text { lacking in the match. } \\
\text { After that the subject } \\
\text { continues to practice } \\
\text { and practice to be able } \\
\text { to cover these } \\
\text { shortcomings. }\end{array}$ & $\begin{array}{l}\text { Significant other sees } \\
\text { the subject is not a } \\
\text { person who quickly } \\
\text { gives up. When } \\
\text { losing, the subject } \\
\text { will be more silent } \\
\text { and contemplate his } \\
\text { defeat. But the } \\
\text { subject also quickly } \\
\text { emerged from defeat } \\
\text { and remained even } \\
\text { more eager to } \\
\text { practice }\end{array}$ & $\begin{array}{l}\text { The subject is not a } \\
\text { person who gives up } \\
\text { easily. Even though } \\
\text { they lose a match, the } \\
\text { subject still tries and } \\
\text { continues to practice } \\
\text { to cover up their } \\
\text { shortcomings. }\end{array}$ \\
\hline
\end{tabular}

Has a strong resistance to social influences

Independent

Confidence
Subjects in dealing with social influences always looked at whether it was a positive or negative invitation. If the invitation is negative, the subject will subtly decline the invitation.

The subject's family is in Central Java and in Jakarta the subject is an Overseas person. While studying the subject also work as a trainer at one of the private universities.

The subject when someone commented on his decision, the subject did not listen to the person's opinion. The subject tries to show people if the decision the subject makes is right for him. In the competition, the subject did not really listen to the crowd's scorn and the subject kept trying first in each match.
According to significant others, the subject is a person who is not too dependent on his social style or the point of view of his friends. The subject has the lifestyle of an athlete

According to the significant other, the subject's family is in Central Java and The subject migrates in Jakarta. The subject also works as a trainer and as an assistant in teaching in order to make ends meet.

According to significant The subject has good others, the subject does self- confidence. The not really care about the subject did not listen opinions or comments of others. When the subject meets a greater opponent, the subject still has confidence if the subject can still win the match.
Subjects have a strong resistance to social influences. Subjects do not quickly follow the influence of their peers and do not depend on the perspective of their peers.

The subject is an Independent person. Subject is an overseas person and works as a Trainer and assistant trainer to make ends meet in Jakarta.

to other people's opinions about his decision and even subject did not listen to ridicule from the trying in the match. When meeting with a tougher opponent, the subject still believes that the subject will win the match. when competing, the opponent and kept 
Continue Tabel 1.1 Description Locus of Control

\begin{tabular}{|c|c|c|c|c|c|}
\hline No & Theme & & Subject & Significant other & Conclusion \\
\hline \multirow[t]{2}{*}{4} & \multirow[t]{2}{*}{$\begin{array}{l}\text { An } \\
\text { overview of } \\
\text { the external } \\
\text { locus of } \\
\text { control }\end{array}$} & $\begin{array}{l}\text { Thinks that his } \\
\text { life is destiny }\end{array}$ & $\begin{array}{l}\text { The subject believes } \\
\text { that what happens to } \\
\text { him is already the } \\
\text { destiny of the } \\
\text { Almighty. Even so, } \\
\text { the subject does not } \\
\text { surrender to fate, the } \\
\text { subject keeps trying in } \\
\text { every competition. }\end{array}$ & $\begin{array}{l}\text { According to the } \\
\text { significant other, the } \\
\text { subject looks more at } \\
\text { his own abilities. Even } \\
\text { if he loses or fails, the } \\
\text { subject sees more of his } \\
\text { own shortcomings. }\end{array}$ & $\begin{array}{l}\text { The subject believes } \\
\text { what happens to him is } \\
\text { predestined. Even so, } \\
\text { the subject did not } \\
\text { surrender to this destiny } \\
\text { and the subject kept } \\
\text { trying in his match. }\end{array}$ \\
\hline & & $\begin{array}{l}\text { Ask parents for } \\
\text { their opinions }\end{array}$ & $\begin{array}{l}\text { Before making a } \\
\text { decision, the subject first } \\
\text { asked his parents what } \\
\text { decision he would make. } \\
\text { Then the subject will } \\
\text { make up his own mind. }\end{array}$ & $\begin{array}{l}\text { According to the } \\
\text { significant other, the } \\
\text { subject in making } \\
\text { decisions from the } \\
\text { subject himself. The } \\
\text { subject also listened more } \\
\text { to the suggestions of } \\
\text { parents in making } \\
\text { decision }\end{array}$ & $\begin{array}{l}\text { The subject, before } \\
\text { making a decision, } \\
\text { always asks his parents } \\
\text { and listens to suggestions } \\
\text { from parents. After that } \\
\text { the subject himself } \\
\text { decides the decisions he } \\
\text { will take. }\end{array}$ \\
\hline
\end{tabular}

Based on the results of interviews between subjects and significant other, there is a common opinion which states that the subject is an athlete who has an internal orientation, the subject has a confident attitude in facing the competition and still believes that he will win the match even though he meets an opponent who is better than him. The subject is independent because he is a foreigner and starts looking for his own income by becoming a coach and assistant coach of wushu sanshao. The subject is also very disciplined in the family, the subject tries his best not to trouble his parents. The subject also behaves actively in his life, not only accepting what has been given, but the subject participates actively in socializing and being mature in dealing with the influences and pressures that are around him, both positive and negative. The subject believes that what happens in his life is destiny, however, it does not make the subject just surrender to destiny, but the subject keeps trying in his match. Subjects also in making a decision always ask their parents' opinion about the good or bad decisions to be taken. After receiving advice from parents, the subject will make his own decisions about what to do. 
Tabel 1.2. Factors That Form Locus of control

\begin{tabular}{|c|c|c|c|}
\hline $\begin{array}{c}\text { Locus of control } \\
\text { factors }\end{array}$ & Subject & Significant other & Conclusion \\
\hline Age & $\begin{array}{l}\text { the subject is getting } \\
\text { more mature in making } \\
\text { every } \\
\text { decision. If in the past } \\
\text { the subject used the ego } \\
\text { more, now the subject } \\
\text { first sees the positive } \\
\text { and negative sides of } \\
\text { the decisions } \\
\text { he will make }\end{array}$ & $\begin{array}{l}\text { According to the } \\
\text { significant other, } \\
\text { currently the subject is } \\
\text { wiser in dealing with his } \\
\text { defeat }\end{array}$ & $\begin{array}{l}\text { It appears that there is a match } \\
\text { between the subject and the } \\
\text { significant other. The subject at } \\
\text { this point is wiser in making } \\
\text { decisions and responding to } \\
\text { losing matches. }\end{array}$ \\
\hline Family & $\begin{array}{l}\text { The subject's parents } \\
\text { apply democratic } \\
\text { parenting and make the } \\
\text { subject think more } \\
\text { creatively. The subject } \\
\text { also felt that he was } \\
\text { given the trust and } \\
\text { opportunity to show his } \\
\text { business in } \\
\text { front of his parents }\end{array}$ & $\begin{array}{l}\text { According to the } \\
\text { significant other, family is } \\
\text { an important thing for the } \\
\text { subject. His family also } \\
\text { always provides full } \\
\text { support when the subject } \\
\text { will compete. }\end{array}$ & $\begin{array}{l}\text { Here there is a match between } \\
\text { the subject's opinion and the } \\
\text { significant other. Family is } \\
\text { important for the subject and } \\
\text { the subject gets full support } \\
\text { from the family for all decisions } \\
\text { he makes. }\end{array}$ \\
\hline Environment & $\begin{array}{l}\text { His current } \\
\text { environment is very } \\
\text { good and has a good } \\
\text { influence on him, } \\
\text { especially giving a } \\
\text { strong influence so that } \\
\text { the subject can excel in } \\
\text { his career as a wushu } \\
\text { athlete. And the subject } \\
\text { is never affected by } \\
\text { negative suggestions } \\
\text { from his friends. }\end{array}$ & $\begin{array}{l}\text { According to the } \\
\text { significant other, the } \\
\text { subject currently lives in } \\
\text { an environment that } \\
\text { provides a good } \\
\text { influence. } \\
\text { environment in which he is } \\
\text { now also helps the subject } \\
\text { to achieve even more in } \\
\text { wushu. The subject is } \\
\text { never affected by the } \\
\text { lifestyle of his friends. }\end{array}$ & $\begin{array}{l}\text { There is a match between the } \\
\text { subject and the significant } \\
\text { other. The environment in } \\
\text { which the subject currently } \\
\text { lives has a good effect on the } \\
\text { subject. The subject is also not } \\
\text { easily influenced by negative } \\
\text { suggestions from his friends } \\
\text { and is not affected by the } \\
\text { lifestyle of his friends. }\end{array}$ \\
\hline
\end{tabular}

Based on the results of interviews conducted by researchers with the subject and significant other, there is a common opinion that the factors that support the subject to have a good internal locus of control are age, family and the subject's social environment. With the increasing age of the subject, the stronger the ability of the subject's internal locus of control, as well as parenting, a good form of family support can support the subject to be internally oriented. Because he has been equipped with good internal abilities from the family, then when he is in a social environment, the subject has no more difficulty controlling himself. 


\section{Conclusion}

based on the results of the study, it can be concluded that:

1. Overview of the Subject's Locus of control

The subject has the characteristics of an athlete with a locus of control that tends to be internal, this can be seen from the subject's efforts to achieve his life goals, the subject does not give up easily and gives up in the face of a competition. The subject chooses to keep trying in a match even though the opponent is very difficult. In making a decision, the subject always asks the parents first after that the subject himself decides without coercion from any party. If the decision is wrong, the subject never blames others, the subject will correct himself and try to correct it. The subject argues that whatever happens in him can be controlled by himself, the subject is a figure who does not give up easily, when the subject experiences a defeat the subject will immediately rise up and learn from his defeat and keep trying to continue in his practice. The influence and social pressure that he had experienced, used the subject as motivation to make himself better.

\section{Factors Affecting Locus of control in Subjects}

The factors that influence the subject's locus of control include age, family and environment. First, the age factor, the subject feels increasingly able to control his environment as he gets older, the subject is able to increase confidence in the internal control he has. Tend to be more independent and think more mature. The two factors of family, family also affect the internal locus of control that the subject has, the more the subject is given the opportunity to influence the environment and himself, the more the subject tends to have an internal orientation, such as the subject's family who is warm, understanding and full of affection also has a big influence in the life of the subject. Third, the social environment, a social environment that has good communication and respects each other is an influence that makes the subject have a good internal as well. The subject tries not to do things that deviate from religious and cultural norms.

\section{Reference}

Arikunto, Suharsimi. (2002). Metodologi penelitian. Jakarta: Penerbit PT. Rineka Cipta.

Asthiningsih Ni Wayan Wiwin ,Carla R dan Mariyono. (2010) Hubungan kemampuan control diri dengan kecenderungan depresi pada mahasiswa program B PSIK FK UGM. Yogyakarta : Jurnal FK UGM, Yogyakarta

Baron, R.A., Byrne, D. and Kantowitz, B.H. 1980. Psychologi understanding behavior second Edition.Tokyo : Haltz-sanders, Ltd.

Basuki, Heru. (2006)Penelitian kualitatif untuk ilmu-ilmu kemanusiaan dan budaya. Jakarta: Gunadarma

Coop, R.H. and White, K. (1974). Psychological concept in the classroom. New York : Harper and Row Publisher.

Denhardt, B. Robert.(1984). Theories of public organization, California: Brooks/Cole Publishing Company, Pacific Grove

Gunarsa, D. Singgih, dkk. (1996). Psikologi olahraga ; Teory dan praktik. Jakarta : PT. BPK Gunung Mulia.

Jung, T. (1978). Understanding human motivation a cognitive approach. New York: John Willwey and Son. Inc.

Kreitner, R. and Kinicki, A. (2004). Organizational behavior. Fifth Edition. New York: McGraw Hill.

Lina \& Rasyid, H.F. (1997). Perilaku konsumtif berdasarkan locus of control pada remaja putra. Jurnal Psikologika, 4 , Hal 24-28 
Martin, R. A., \& Lefcourt, H. M. 1983. Sense of Humor as a Moderator of The Relation Between Stressor and Moods. Journal of Personality and SocialPsychology, 45, 121- 129.

Moleong, J. Lexy. (1998) Metodologi penelitian kulitatif . Bandung : Rosda Karya

Moleong, J. Lexy. (2004) Metodologi penelitian kulitatif . Bandung : Rosda Karya

Pate, Russel R., Bruce Mc.Clenaghan, and Robert Rotella, (1984), Scientific Foundation of Coaching, New York : Saunders College Publishing.

Patton,M.Q. (1990). Qualitative evaluation and research methods. Newburry Park: Sage Publications.

Phares, E.J. (1976) Locus Of Control in Personality, New Jersey, General Learning Press.

Phares, E.J. (1992). Clinical Psychology, Concepts, Methods and Profession. 4 th ed. Kansas

: Brooks/Cole Publishing Co

Poerwandari, Kristi. (2001). Pendekatan kualitatif untuk penelitian perilaku manusia.

Fakultas Psikologi, Universitas Indonesia : Lembaga Pengembangan Sarana

Pengukuran dan Pendidikan Psikologi (LPSP3).

Poerwandari, E. Kristi. (2005) Pendekatan kualitatif dalam penelitian psikologi. Jakarta: LPSP3 Fakultas Psikologi Universitas Indonesia

Poerwandari, E. Kristi. (2007). Pendekatan Kualitatif untuk Penelitian Perilaku Manusia.

Jakarta: Lembaga Pengembangan Sarana Pengukuran dan Pendidikan Psikologi UI.

Robbins, Stephen P dan Timothy A. Judges. (2007).Perilaku organisasi,

(Organizational behavior).Buku 1. Jakarta : Salemba Empat

Robbins, S.P. (1989). Organizational behavior : Controversies and aplication, Fourth Edition.

New Jersey : Prentice Hall International Inc.

Rotter J, B. (1966). Generalized expectancies for internal versus external control

of reinforcement psychological monograph agneral and applied, 80.

Sachs, M. L. (1993). Professional ethics in sport psychology. In R. N. Singer, M. Murphey, \&

L. K. Tennant (Ed.), Handbook of research in sport psychology (pp. 921-932). New York: Maacmillan.

Schultz, D., \& Schultz, S.E. (1994). Theories of Personality 5th Edition. California : Brooks/Cole.

Setyobroto, S. (1993). Psikologi Kepelatihan. Jakarta:CV Jaya Sakti

Yin, Robert. K. (2002) Studi kasus desain dan metode, Jakarta : Raja Grafindo Persada

Sugono. Dendy. (2008). Kamus Besar Bahasa Indonesia edisi keempat. Jakarta : Balai Pustaka.

Tunggal,Setia Hadi. (2006). Undang-Undang Sistem Keolahragaan Nasional (Undang- Undang Republik Indonesia Nomor 3 Tahun 2005), Jakarta :Harvarindo

Zaroh, W. (2000). Hubungan antara locus of control dan tipe kepribadian dengan persepsi beban kerja pada pengemudi bus malam jurusan solo-jakarta. Tesis. Depok : Fakultas Psikologi Universitas Indonesia: Tidak Diterbitkan

Zimbardo, P.G. (1980) Essentials of psychology And Life. 10th. USA : Scott

Zymbardo, P.G. and Gerrig, R.J. 1999. Psychology and Life, Fifteenth Edition. New York : Longman. 